\title{
Article \\ Characterization of Underlying Twin Shield Tunnels Due to Foundation-Excavation Unloading in Soft Soils: An Experimental and Numerical Study
}

\author{
Xiaodong Cheng ${ }^{1,2}$, Tianqiu Hong ${ }^{1}$, Zhitang Lu ${ }^{1, *}$ and Xiaochun Cheng ${ }^{2}$ \\ 1 School of Resources and Environmental Engineering, Hefei University of Technology, Hefei 230009, China; \\ 2011010073@mail.hfut.edu.cn (X.C.); hongtianqiu@hfut.edu.cn (T.H.) \\ 2 Anhui Lianzhi Engineering Testing Co., Ltd., Hefei 231200, China; honorwxl@163.com \\ * Correspondence: zhitang.lu@hfut.edu.cn
}

Citation: Cheng, X.; Hong, T.; Lu, Z.; Cheng, X. Characterization of

Underlying Twin Shield Tunnels Due to Foundation-Excavation Unloading in Soft Soils: An Experimental and Numerical Study. Appl. Sci. 2021, 11, 10938. https://doi.org/10.3390/ app112210938

Academic Editor: Daniel Dias

Received: 18 October 2021

Accepted: 17 November 2021

Published: 19 November 2021

Publisher's Note: MDPI stays neutral with regard to jurisdictional claims in published maps and institutional affiliations.

Copyright: () 2021 by the authors. Licensee MDPI, Basel, Switzerland. This article is an open access article distributed under the terms and conditions of the Creative Commons Attribution (CC BY) license (https:// creativecommons.org/licenses/by/ $4.0 /)$.

\begin{abstract}
Excavation near or above existing shield tunnels often results in adverse impacts on tunnel stability. To ensure the serviceability of existing tunnels, this paper presents experimental and numerical studies with reference to a foundation pit case history excavated above twin-tube shield tunnels in soft soils. The experimental tests were firstly applied to study the deformation characteristics and structural response of the shield tunnels. Thereafter, an extensive numerical investigation was performed to determine the influence of some factors such as cover-to-excavation depth ratio, length-to-depth ratio, and unloading ratio on tunnel displacement behaviors. It was demonstrated that the tunnel heaves as the excavation proceeds, and heaves and horizontal displacements reach their maximum values when the excavation is finished. The earth pressure around the tunnels is symmetrically distributed in a gourd shape, with a larger reduction at the tunnel crown and invert and a smaller reduction at tunnel side walls. Additionally, the earth pressure at the tunnel crown and invert changes more significantly than that at other parts. The tunnel moment increment is significantly affected by the tunnel excavation depth. The axial force at or near the side walls of the tunnel is the most sensitive to the unloading effect induced by the excavation activity.
\end{abstract}

Keywords: foundation excavation; shield tunnel; tunnel response; parametric study

\section{Introduction}

Currently, urban rail transit systems have served as a favorable means to expedite the modernization of cities [1]. An increasing number of subway tunnels have been developed to alleviate congestion in urban transportation systems [2,3]. Shield-driven tunneling offers the advantages of high efficiency, low cost, and low interference with the surrounding environment, which makes it one of the most advanced and popular tunneling techniques [4]. Therefore, it is extensively utilized in the construction of shield tunnels in urban areas [5,6]. With the increasing development of underground space, the construction of infrastructure in dense cities often encounters existing underground structures and facilities, such as municipal pipelines, underground corridors and interdistrict tunnels, etc. $[7,8]$. Therefore, the effects of unloading caused by adjacent or above excavation on the existing structures, especially on the existing tunnels, is of increasing concern $[9,10]$.

However, the interaction mechanism between the existing tunnel and adjacent or above unloading action is very complex. The response of the tunnel is closely dependent on the tunnel sizes [11,12], excavation dimensions and/or methods [13], excavation protective measures [14], and the location relationship between tunnel and excavation [15], etc. The interaction between existing tunnels and excavation have been widely investigated by employing the means of the numerical simulations [16,17], physical model tests [18], field observations [19], and theoretical analysis [20]. Meng et al. [21] reviewed the contributions to responses of existing tunnel subjected to nearby excavation, which is helpful to reveal 
general knowledge of the relevant problems and to provide guidance for more in-depth research. Li et al. [22] developed a 3D numerical model with ABAQUS to simulate the actual process of a new construction method (i.e., divided alternate excavation methodDAEM) in an excavation of a deep foundation pit above shield tunnels. Thereafter, the effectiveness of DAEM in controlling deformation of the underneath tunnel is confirmed by comparing the results with the other two conventional excavation methods. Ng et al. [23] conducted a series of three-dimensional centrifugal tests to investigate the effects of sand density and basement wall stiffness on the basement-tunnel interaction, and then they developed a computational chart as a design tool. They reported that the excavationinduced heave and transversal strain were more sensitive to the changes in soil density in the transverse direction than those in longitudinal direction when the basement was constructed directly over the existing tunnel. Moreover, when the basement was built on the side of the existing tunnel, the diaphragm wall was more effective than the sheet pile wall in terms of controlling settlement and tensile strains of tunnels. Liu et al. [24] reported that a series of hazards such as water seepage, concrete spalling, and segment cracks occurred when a station-expansion project was conducted beside the tunnels. Additionally, they further discussed the causes responsible for these hazards based on the performed numerical and theoretical investigations. Sharma et al. [25] examined the effects of a large excavation nearby a $6 \mathrm{~m}$-diameter MRT tunnel by using field-monitoring data and finite element analysis, and confirmed that the lining stiffness possesses a significant effect on tunnel displacement induced by the adjacent excavation. They reported that the stiffer lining underwent less displacement but may experience larger bending moments. Zhang et al. [26] proposed a simplified analytical model for analyzing the deformation response of excavation-induced soil unloading on adjacent tunnels. The model could determine the tunnel deformation response by considering the soil unloading and Galerkin method. Han et al. [27] proposed a cracks risk assessment method for existing tunnels. The singular function method was used to calculate the longitudinal deformation and structural internal forces. Thereafter, the relationship between annular seam opening and additional bending moment could be established based on the equivalent axial stiffness theory. Zheng et al. [28] conducted a finite element analysis using the small-strain stiffness and hardened soil model to investigate the effects of the excavation depth, horizontal displacement of the support structure, and relative excavation position on the response of an existing tunnel. A simplified semiempirical model to assess the lateral adjacent excavation deformation of the tunnel was then developed based on the numerical results. In summary, these findings regarding the assessment of the existing tunnels' responses to excavation activities are of great interest for preliminary design and engineering practice.

Of course, it is crucial to ensure the safety and availability of the existing tunnels, since excavation activities can change the initial ground stress state and lead to free soil movements $[29,30]$. Theoretically, the response of the existing tunnels caused by the excavation are the result of the interaction between the disturbed soil motion and the existing tunnel bearing capacity [31,32]. The construction of foundation pits in soft soils is often accompanied by extremely strong environmental effects, which will inevitably have an adverse effect on the existing tunnel, such as additional loads and bending moments. The literature review revealed that previous studies have focused on the impact of pitunderlying single-line tunnel with a single parameter. However, the impact of pit unloading construction on underground twin-tube tunnels, or the analysis of multiparameter impacts, have received little attention. This issue needs to be further understood. In view of this, an experimental test was carried out to study tunnel-soil interaction traits with reference to a pit unloading above the tunnel in soft soils. In-depth, three-dimensional numerical analysis was then performed to systematically investigate various factors on the response of the underlying twin-tube tunnels. 


\section{Project Overview}

The case history of the foundation pit and the underneath shield tunnel in operation are essentially orthogonal to each other in plane, and their location relationship is displayed in Figure 1. The twin-tube tunnels are constructed by the shield-driven tunnelling method; the outer diameters $\left(D_{t}\right)$ are $6.0 \mathrm{~m}$ and the inner diameters $\left(d_{t}\right)$ are $5.4 \mathrm{~m}$. The tunnel linings are $C 50$ precast concrete segments with a thickness of $0.3 \mathrm{~m}$. The initial cover depth $\left(C_{t}\right)$ of the tunnels before pit excavation is $17 \mathrm{~m}$, and the clearance $\left(L_{t}\right)$ between the twin tubes is $13.0 \mathrm{~m}$. The foundation pit is about $35 \mathrm{~m}$ in length $\left(L_{p}\right)$ and $20 \mathrm{~m}$ in width $\left(W_{p}\right)$, with a final excavation depth $\left(H_{p}\right)$ of $8 \mathrm{~m}$. It is noted that the foundation pit's side along the tunnel transversal direction is defined as the length $\left(L_{p}\right)$, while the other side along the tunnel longitudinal direction is defined as the width $\left(W_{p}\right)$. The clearance $(H)$ between the crown of tunnels and the bottom of the foundation pit is $9 \mathrm{~m}$. The foundation pit was supported by a diaphragm wall combined with transverse steel support. The final excavation depth $\left(H_{w}\right)$ of the diaphragm wall is $16 \mathrm{~m}$. The C25 concrete is utilized for diaphragm wall construction, with a thickness of $0.8 \mathrm{~m}$. To reduce the deformation of the enclosure structure and enhance the reliability of the foundation pit, the support scheme of setting three-level steel supports along the excavation direction in the foundation pit was adopted. The depths of three-level struts are $1 \mathrm{~m}, 3 \mathrm{~m}$ and $5 \mathrm{~m}$ from ground surface.

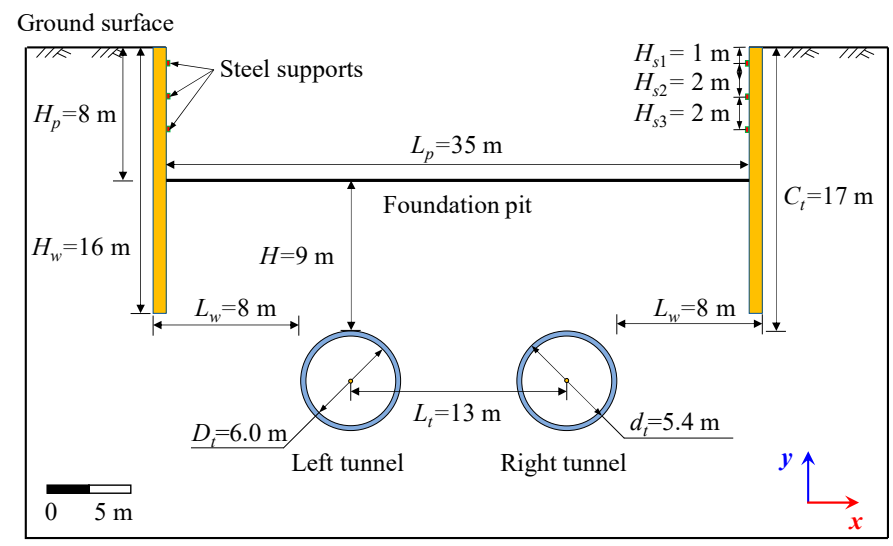

Figure 1. Spatial relationship between the foundation and twin-tube shield tunnels.

The worksite consists of four soil layers within $60 \mathrm{~m}$ depth [33], which are backfilling, silt, silty clay and sand, with thicknesses of $1.5 \mathrm{~m}, 17 \mathrm{~m}, 20 \mathrm{~m}$ and $30 \mathrm{~m}$, respectively. The soil stratigraphic profile in the worksite is shown in Figure 2. It can be seen from the physical and mechanical parameters of the site that the soil weight $(\gamma)$ was in the range of $17.8-21 \mathrm{kN} / \mathrm{m}^{3}$, the elastic modulus $(E)$ was $25-40 \mathrm{MPa}$, Poisson's ratio $(\mu)$ was $0.3-0.31$, the cohesion $(c)$ was $19.6-22 \mathrm{kPa}$, and the internal friction angle $(\varphi)$ was $24-35.6^{\circ}$.

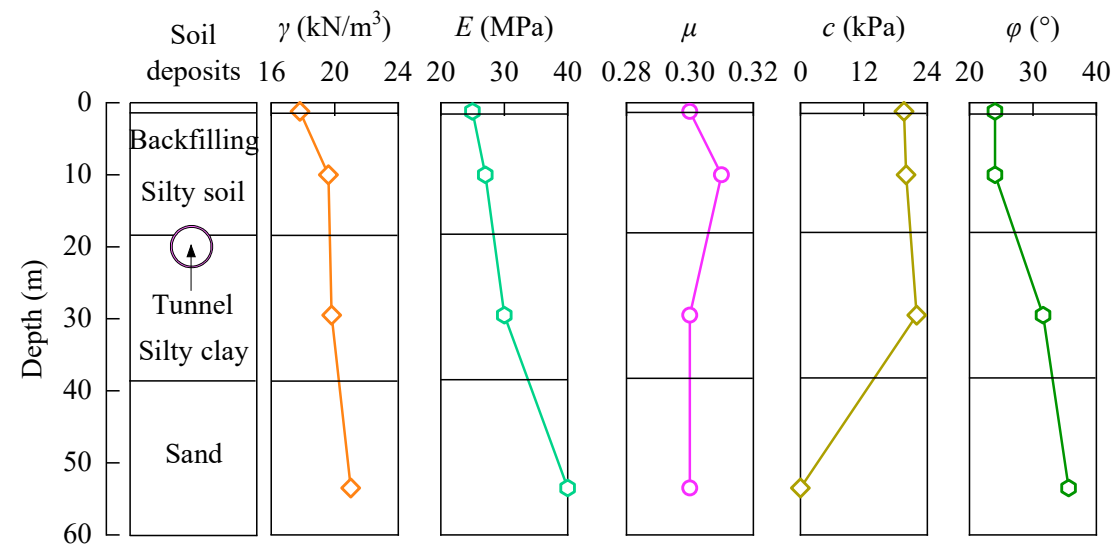

Figure 2. Soil properties profile of worksite [33]. 


\section{Experimental Apparatus}

\subsection{Preparation and Procedure}

Physical model tests are laboratory simulations of the geomechanical problems at a proportionally reduced scale, which are often employed to clarify critical mechanisms, and are an instrument for validation or calibration of numerical models [34,35]. The theory and techniques for statical and geomechanical models were methodically developed by Fumagalli $[34,36]$; thereafter, they have been employed in a variety of engineering practices for stability evaluation $[35,36]$. Similarity theory imposes a set of similarity requirements on physical models in regard to the geometry, physical-mechanical properties, boundary conditions, and initial states. These similarity requirements can be derived from the force equilibrium equations, geometric equations, Hooke's law and boundary conditions according to the elastic-plasticity theory and dimensional analysis [34,37]. Some similarity coefficients, that are defined as the ratios of prototype to model parameters, must be constants. These parameters are geometry, stress, strain, displacement, modulus, Poisson's ratio, cohesion, etc. [34,37].

In the physical model tests, the geometry and unit weight of soils are taken as control physical quantities based on the similarity theory. Thereafter, a 1/20 model scale of the geometry, elastic modulus $(E)$ and cohesion $(c)$, and a 1/1 model scale of the internal friction angle $(\varphi)$, bulk density $(\gamma)$ and Poisson's ratio $(\mu)$ were determined for the experimental tests. The model box size is $4000 \mathrm{~mm} \times 1500 \mathrm{~mm} \times 2000 \mathrm{~mm}$ (length $\times$ width $\times$ height), as shown in Figure 3. The foundation pit's support scheme in the model test is the same as the aforementioned engineering prototype. The model tunnels are made of gypsum mixed with water, and the diaphragm walls are simulated with organic glass. The elastic modulus of the tunnel liner and diaphragm wall in the prototypes were $34.5 \mathrm{GPa}$ and $28 \mathrm{GPa}$, respectively. The elastic modulus of the model tunnel is $1.725 \mathrm{GPa}$, while that of the model diaphragm wall is $1.4 \mathrm{GPa}$. Both of these values comply with the mechanical similarity constant. The model tunnels have a thickness of $15 \mathrm{~mm}$, an outer diameter of $300 \mathrm{~mm}$, an inner diameter of $270 \mathrm{~mm}$, and a length of $1500 \mathrm{~mm}$; the model diaphragm wall has a thickness of $40 \mathrm{~mm}$, a height of $400 \mathrm{~mm}$, a width of $1000 \mathrm{~mm}$, and a length of $1750 \mathrm{~mm}$. The model tunnels and the diaphragm wall were preburied into the soils before the excavation of the foundation pit. The steel supports are simulated by using the thin steel pipes, which are installed in the holes reserved for the connection during the excavation. The photos descripting the experiments are illustrated in Figure 4.

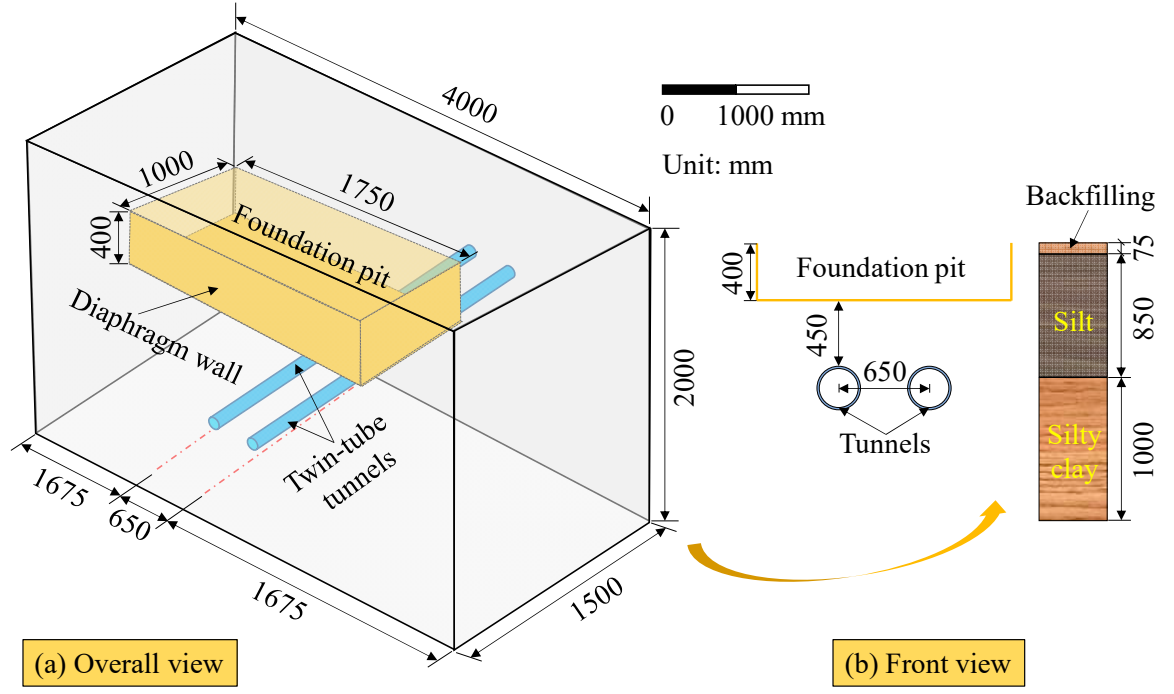

Figure 3. Layout and geometry of the model. 

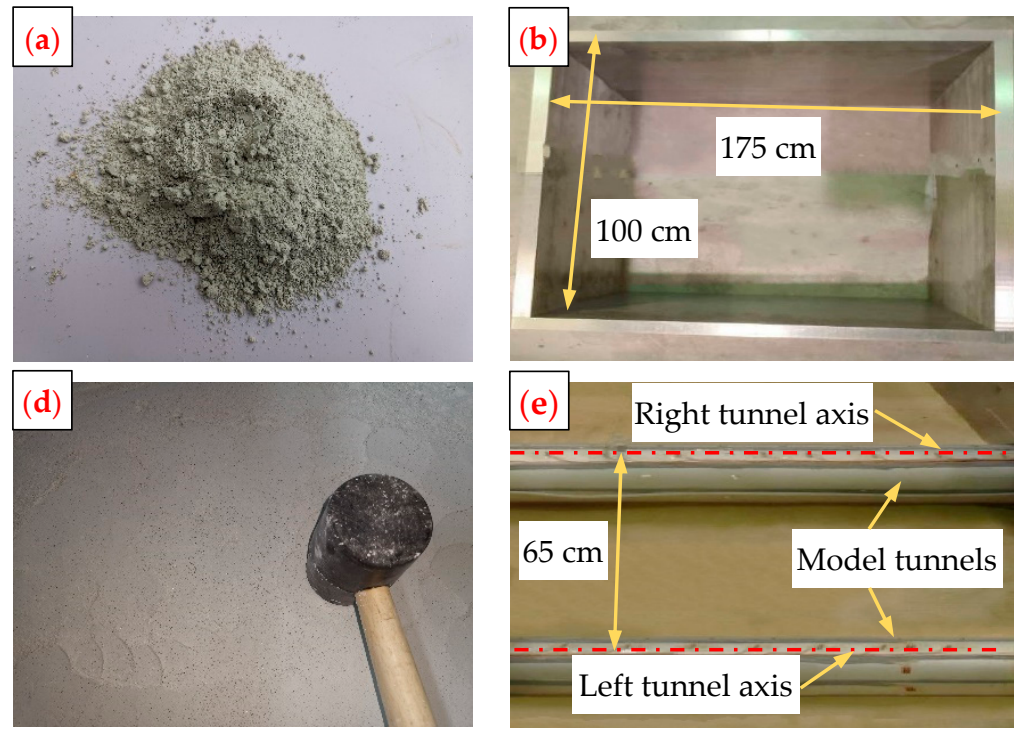
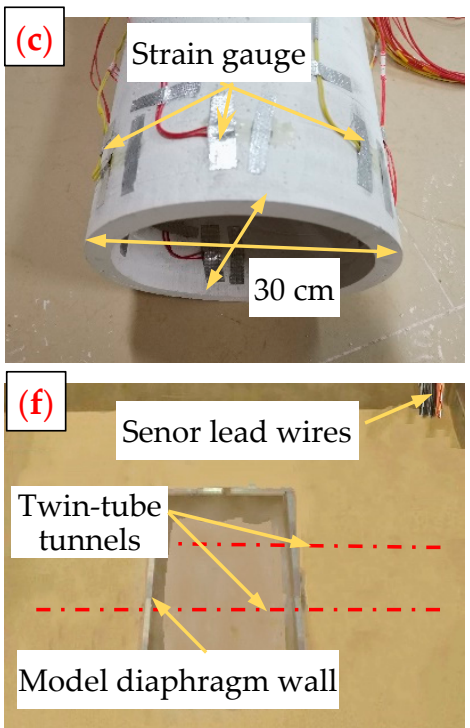

Figure 4. Some photos captured during the experiments, (a) mixed similar materials, (b) model diaphragm wall, (c) model tunnel with strain gauge ready, (d) material compaction (e), installation of twin-tube model tunnel, and (f) installation of model diaphragm wall.

The existing tunnels are mainly located in three soil layers, namely, backfilling, silt and silty clay. Tunnels and the foundation pit were both built above the water table line. Therefore, soil-like materials were prepared in a dry condition, and the groundwater is not considered. The mechanical similarities of soils are employed for realization of the similar materials in physical model tests. The soil-like materials were made with four materials: barite powder (BP), bentonite (BT), gypsum (GP) and lime (LM), of which gypsum and lime were used as the binder. The soil-like material compositions and formulations are shown in Table 1, where the symbols $p$ and $m$ represent prototype and model parameters, respectively.

Table 1. Physical and mechanical parameters of prototype and model materials.

\begin{tabular}{|c|c|c|c|c|c|c|c|c|c|c|c|c|c|}
\hline \multirow{2}{*}{ Soil Deposits } & \multicolumn{2}{|c|}{$\gamma\left(\mathrm{kN} / \mathrm{m}^{3}\right)$} & \multicolumn{2}{|c|}{$E(\mathbf{M P a})$} & \multicolumn{2}{|c|}{$c(\mathbf{k P a})$} & \multicolumn{2}{|c|}{$\varphi\left({ }^{\circ}\right)$} & \multicolumn{2}{|c|}{$\mu$} & \multicolumn{2}{|c|}{$t(\mathrm{~m})$} & \multirow{2}{*}{ Mass Ratio } \\
\hline & $p$ & $m$ & $p$ & $m$ & $p$ & $m$ & $p$ & $m$ & $p$ & $m$ & $p$ & $m$ & \\
\hline Backfilling & 17.8 & 17.8 & 17.8 & 0.89 & 19.6 & 0.98 & 24.0 & 24.0 & 0.30 & 0.30 & 1.5 & 0.075 & BP:BT:GP:LM = 10:8:1:1 \\
\hline Silt & 19.6 & 19.6 & 19.6 & 0.98 & 20.0 & 1.0 & 24.0 & 24.0 & 0.31 & 0.31 & 17.0 & 0.85 & BP:BT:GP:LM = 15:8:1:2 \\
\hline Silty clay & 19.8 & 19.8 & 19.8 & 0.99 & 22.0 & 1.1 & 31.6 & 31.6 & 0.30 & 0.30 & 20.0 & 1.0 & BP:BT:GP:LM = 16:8:1:2 \\
\hline
\end{tabular}

\subsection{Measurement Setup}

After the model material was fully mixed, it was spread evenly into the model box and treated as a smooth wallpaper on the inner walls to reduce the friction effect between the soils and walls. Considering the major construction scheme and conveniency for physical tests, the excavation of the foundation pit was carried out in eight stages as follows: (1) initial state sampling; (2) excavation of the foundation pit to $2 \mathrm{~m}$; (3) first transverse steel support; (4) excavation of the foundation pit to $4 \mathrm{~m}$; (5) second transverse steel support; (6) excavation of the foundation pit to $6 \mathrm{~m}$; (7) third transverse steel support; (8) excavation of the foundation pit to $8 \mathrm{~m}$.

Given that the tunnel section directly below the foundation pit is most significantly affected by excavation, this section was chosen for the follow-up systematic analysis. The tunnel displacement is measured by pull-wire displacement sensors of a 0-100 $\mathrm{mm}$ measurement range with an accuracy of $0.01 \mathrm{~mm}$, which meet the test accuracy requirements. The earth pressure is measured by YT-200G earth pressure cells. Strain gauges were utilized for monitoring the strains inside and outside the tunnel liners for the conversion of bending moments and axial forces. Figure 5 illustrates the sensors used for physical tests. The 
tunnel is arranged with 16 monitoring points along the transverse section with an equal counterclockwise interval. The points at left tunnel are named L1-L16 while the ones at left tunnel are named R1-R16, respectively. These 16 measurement points are arranged with earth pressure cells and strain gauges. The displacement sensors were arranged at the tunnel crown, invert and side wall. For example, measurement points L5 and R13 are used to measure the horizontal displacements of the tunnels, while L9 and R9 are utilized to measure the tunnel heaves. All earth pressure cells are applied to measure the radial earth pressure around the tunnel. The arrangement of pull-wire displacement sensors and earth pressure cells and strain gauges is shown in Figure 6.

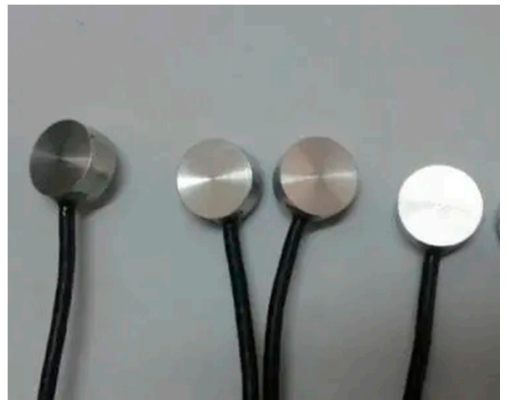

(a)

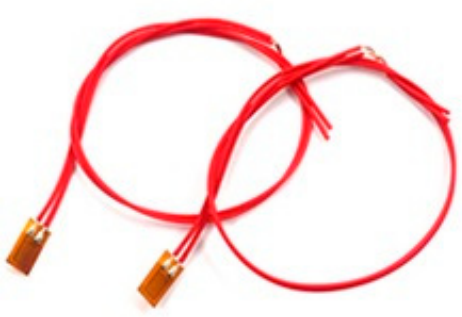

(b)

Figure 5. Photos of the sensors used in experimental tests. (a) earth pressure cell, (b) strain gauge.

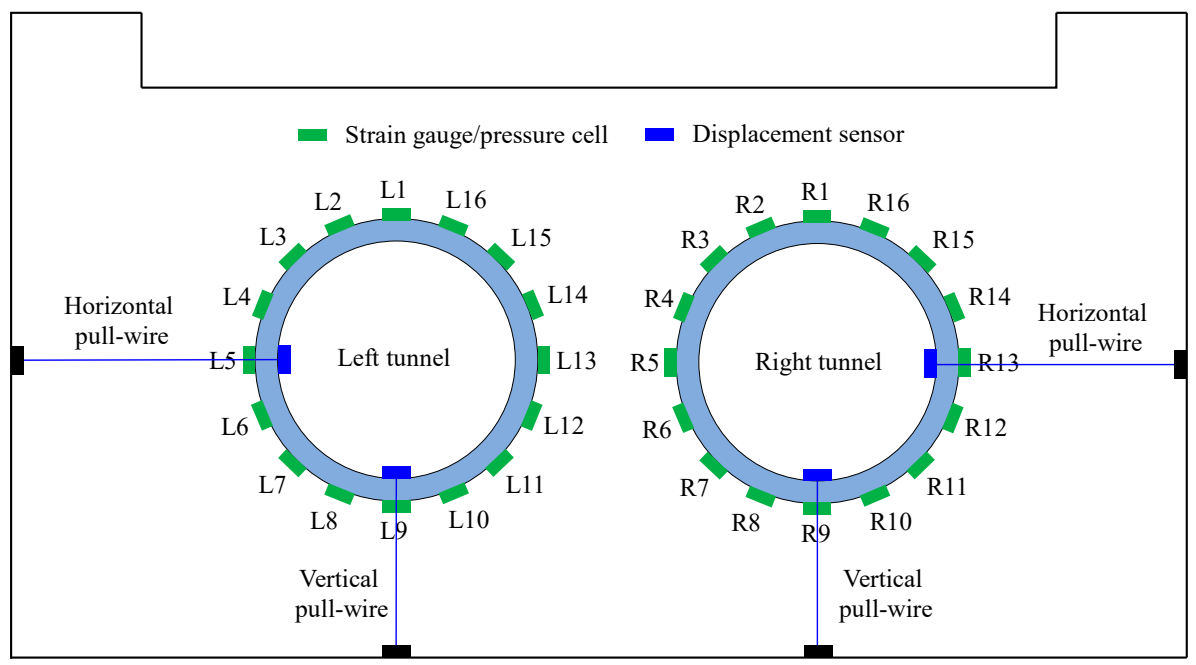

Figure 6. Arrangement of measuring sensors.

\section{Results and Discussion}

\subsection{Tunnel Deformation}

The measured displacements of the tunnels by the pull-wire displacement sensors in prototype scale are plotted in Figure 7, where positive values of vertical displacement indicate tunnel heave. It can be seen that the heaves of both tunnels experience the same tendency. With the increasing excavation depth of the foundation pit, the tunnel heave gradually increases, and then reaches the maximum when excavating to the bottom of the foundation pit. The measured heave at left tunnel is $9.88 \mathrm{~mm}$ while that at right tunnel is $10.22 \mathrm{~mm}$. At the same time, an insignificant difference in tunnel heaves were observed during the first three excavation stages, but for the fourth excavation stage, the tunnel heave undergoes a more significant increase than in the previous three excavation stages. The horizontal displacements are relatively small throughout the excavation activities, with the maximum displacements of $2.52 \mathrm{~mm}$ and $2.47 \mathrm{~mm}$ at the left and right tunnel, respectively. Unlike tunnel heave, horizontal displacements in the tunnel are more sensitive 
to the changes in excavation depth. Although the effect of the first two excavation stages on the horizontal displacement of the tunnel is marginal, it undergoes a more pronounced shift in the third excavation stage (i.e., stage six). The deformation responses of the twin-tube tunnels at different stages are drawn and displayed in Figure 8. It reveals the fact that the latter two excavation stages produced an obvious increase in horizontal displacement, which account for $82.54 \%$ and $80.85 \%$ of the total horizontal displacement of the left and right tunnels. Moreover, both tunnels are observed to be significantly displaced toward the center of the foundation pit with excavation advancement.
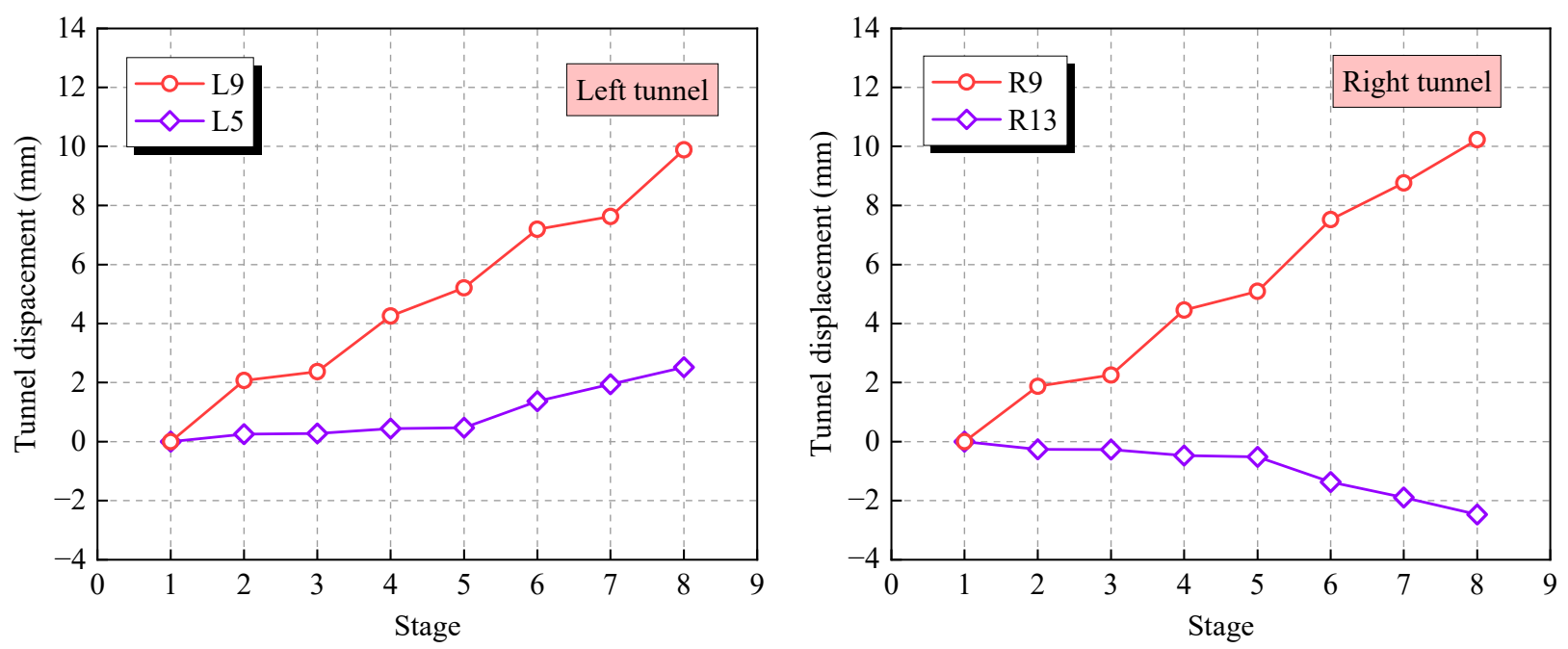

Figure 7. Tunnel displacement with construction simulation stage.

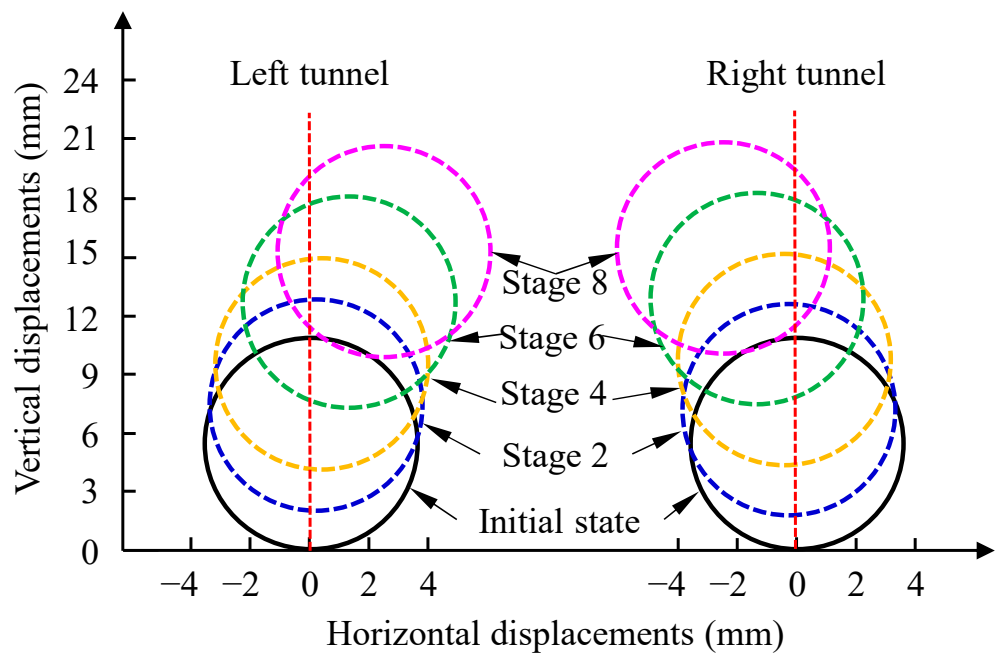

Figure 8. Tunnel deformation responses for different excavation stages.

\subsection{Additional Earth Pressure}

The measured earth pressure at points 1, 5, 9 and 13 are displayed in Figure 9, and the final distributions of earth pressure around tunnels before and after excavation are plotted in Figure 10. As can be seen from Figure 9, the vertical earth pressure at monitoring points L1, L9, R1 and R9 gradually decreased with the excavation of the foundation pit. When the excavation was completed, the vertical earth pressure was reduced to the minimum value of $58.27 \mathrm{kPa}$ and $55.21 \mathrm{kPa}$ at crowns, and of $83.47 \mathrm{kPa}$ and $91.75 \mathrm{kPa}$ at inverts of the left and right tunnels. The horizontal earth pressure at monitoring point 13 underwent the same trend as the vertical earth pressure at monitoring point 1 for different stages. Figure 10 displays the fact that, during the excavation and unloading of the foundation pit, the earth pressure around the tunnels is roughly gourd-shaped and symmetrically 
distributed. The measured earth pressure values at monitoring points 1, 5, 9 and 13 were utilized to derive the pressure ratios before and after the excavation of the foundation pit, which are summarized in Table 2 . The reductions in the earth pressure at crowns of the left and right tunnels are $68.06 \%$ and $70.22 \%$, while those at the inverts are $63.69 \%$ and $59.44 \%$, respectively. Moreover, the reductions in earth pressure at the tunnel side walls are smaller than these at the crowns and inverts of the tunnels. This confirms a larger stress relief magnitude at the tunnels' crowns and inverts than that at side walls. Additionally, the reduction in earth pressure at the tunnel side walls that are away from the foundation pit is slightly larger than the other side wall, near the foundation pit.
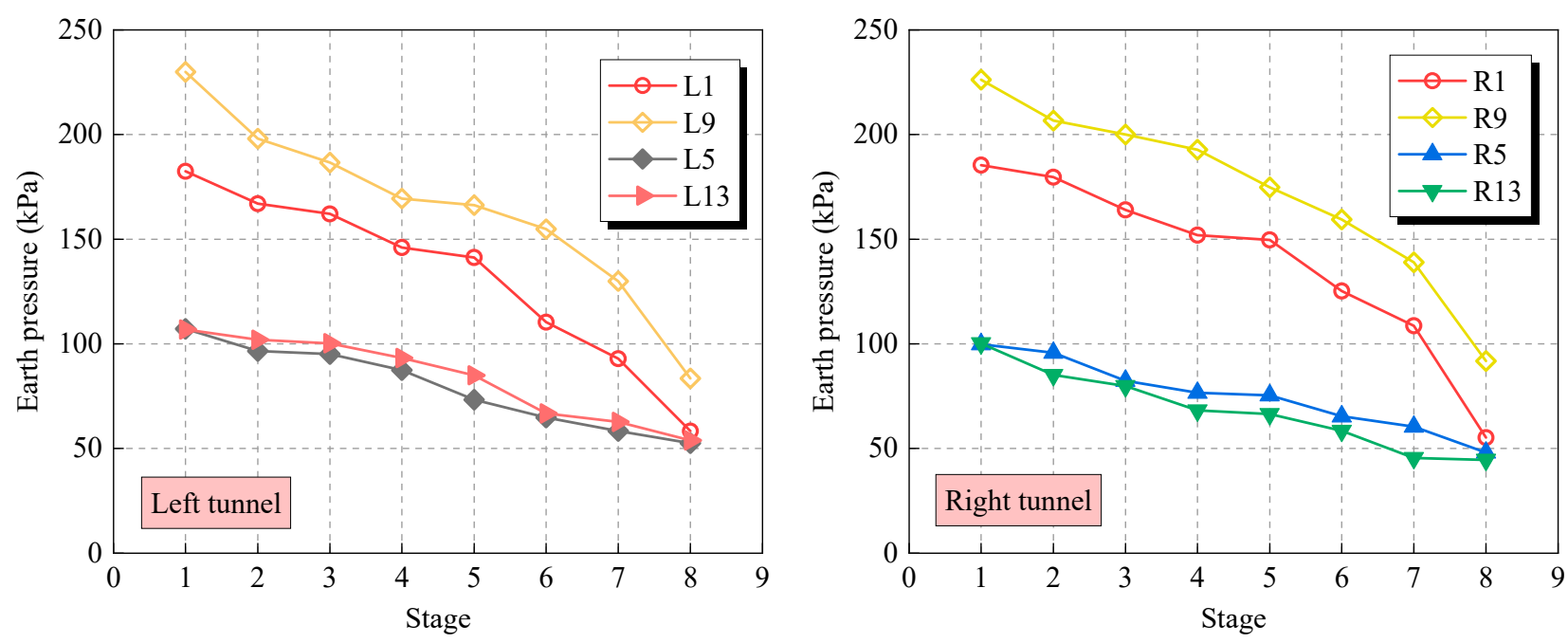

Figure 9. The earth pressure curve for different construction stages.
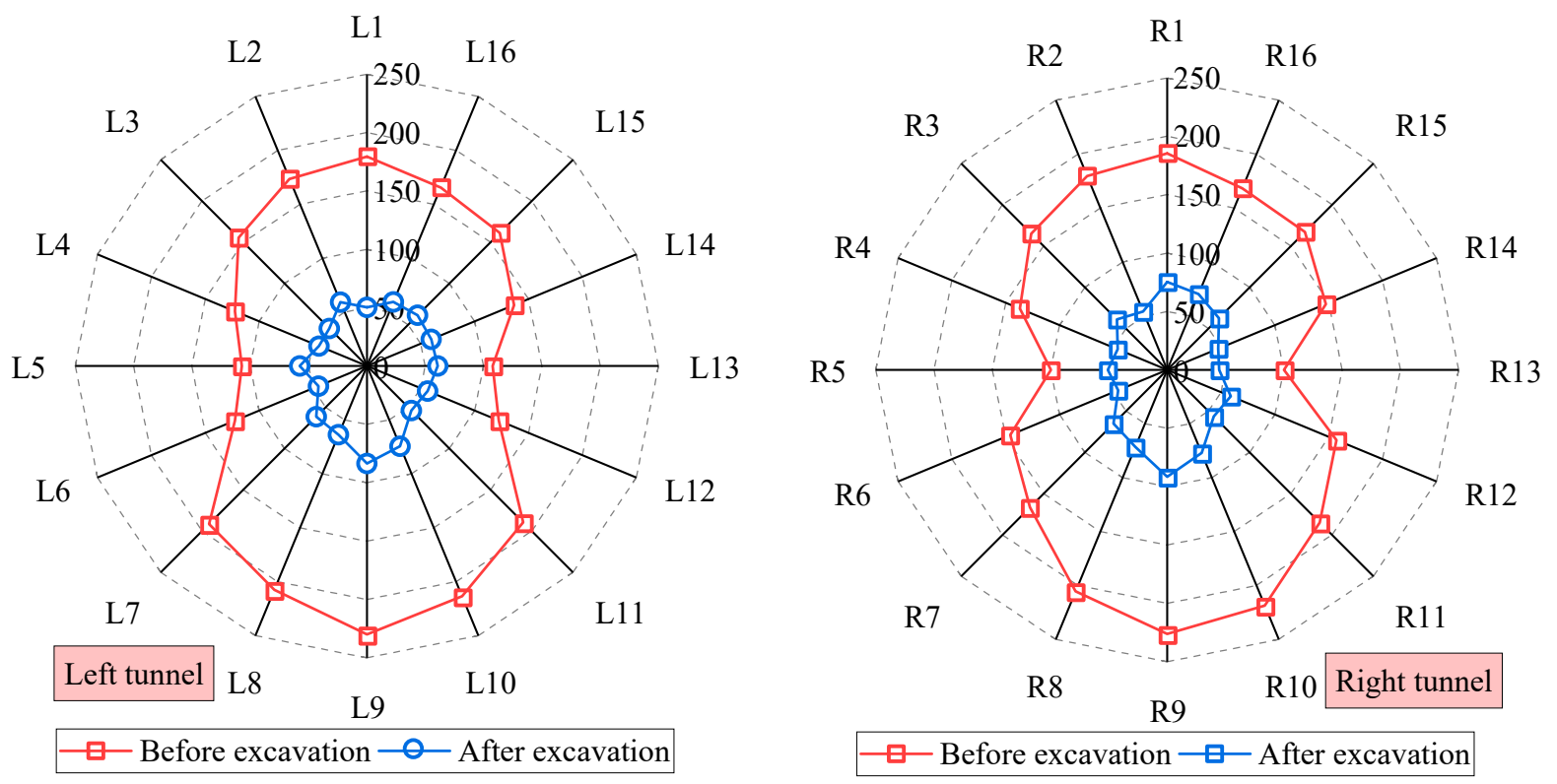

Figure 10. Variations of earth pressure around tunnel before and after excavation (unit: $\mathrm{kPa}$ ). 
Table 2. Variations of earth pressure around tunnel before and after excavation (unit: $\mathrm{kPa}$ ).

\begin{tabular}{|c|c|c|c|c|}
\hline \multirow{2}{*}{ Type } & \multirow{2}{*}{ Monitoring Points } & \multicolumn{2}{|c|}{ Value } & \multirow{2}{*}{ Ratio (\%) } \\
\hline & & Before & After & \\
\hline \multirow{4}{*}{ Vertical } & L1 & 182.41 & 58.27 & 31.94 \\
\hline & L9 & 229.91 & 83.47 & 36.31 \\
\hline & R1 & 185.41 & 55.21 & 29.78 \\
\hline & $\mathrm{R} 9$ & 226.20 & 91.75 & 40.56 \\
\hline \multirow{4}{*}{ Horizontal } & L5 & 107.17 & 52.51 & 48.99 \\
\hline & L13 & 106.84 & 53.86 & 50.41 \\
\hline & R5 & 99.81 & 48.03 & 48.12 \\
\hline & $\mathrm{R} 13$ & 100.24 & 44.57 & 44.46 \\
\hline
\end{tabular}

\subsection{Tunnel Bending Moment}

The bending moments measured at transverse sections of left and right tunnels after four excavation stages are plotted in Figure 11. The positive values of tunnel bending moments denote the outer side compressive moment and inner side tensile moment, while the negative values denote the opposite condition. It is demonstrated that the tunnel crowns and inverts are mainly under tension, while the side walls are mainly under compression. The tunnel bending moment increases with the increasing excavation depth of the foundation pit, and the variations are more pronounced at the crowns and inverts. The maximum positive bending moments of the left and right tunnels are $52.49 \mathrm{kN} \cdot \mathrm{m}$ and $53.56 \mathrm{kN} \cdot \mathrm{m}$, respectively, and both of them are located at the tunnel inverts, i.e., the L9 and $\mathrm{R} 9$ regions. The maximum negative bending moments are recorded at the $\mathrm{L} 5$ and $\mathrm{R} 13$ regions of the left and right tunnels, and these two values are $-51.31 \mathrm{kN} \cdot \mathrm{m}$ and $-46.76 \mathrm{kN} \cdot \mathrm{m}$, respectively. In addition, the increasing depth of the pit excavation leads to an increasing tunnel bending moment, at an increased rate. However, the increasing trend of the bending moments of the tunnel near the foundation pit side is slightly more pronounced than that far from the foundation pit. The last two excavation stages result in a more significant increase in the bending moments than the first two excavation stages, indicating that the disturbance effect on the tunnel increased as the excavation advances. Therefore, the excavation and corresponding unloading of the foundation pit cause significant disturbance to the tunnels, especially at the measurement points near the pit side, where the bending moment varies more dramatically.
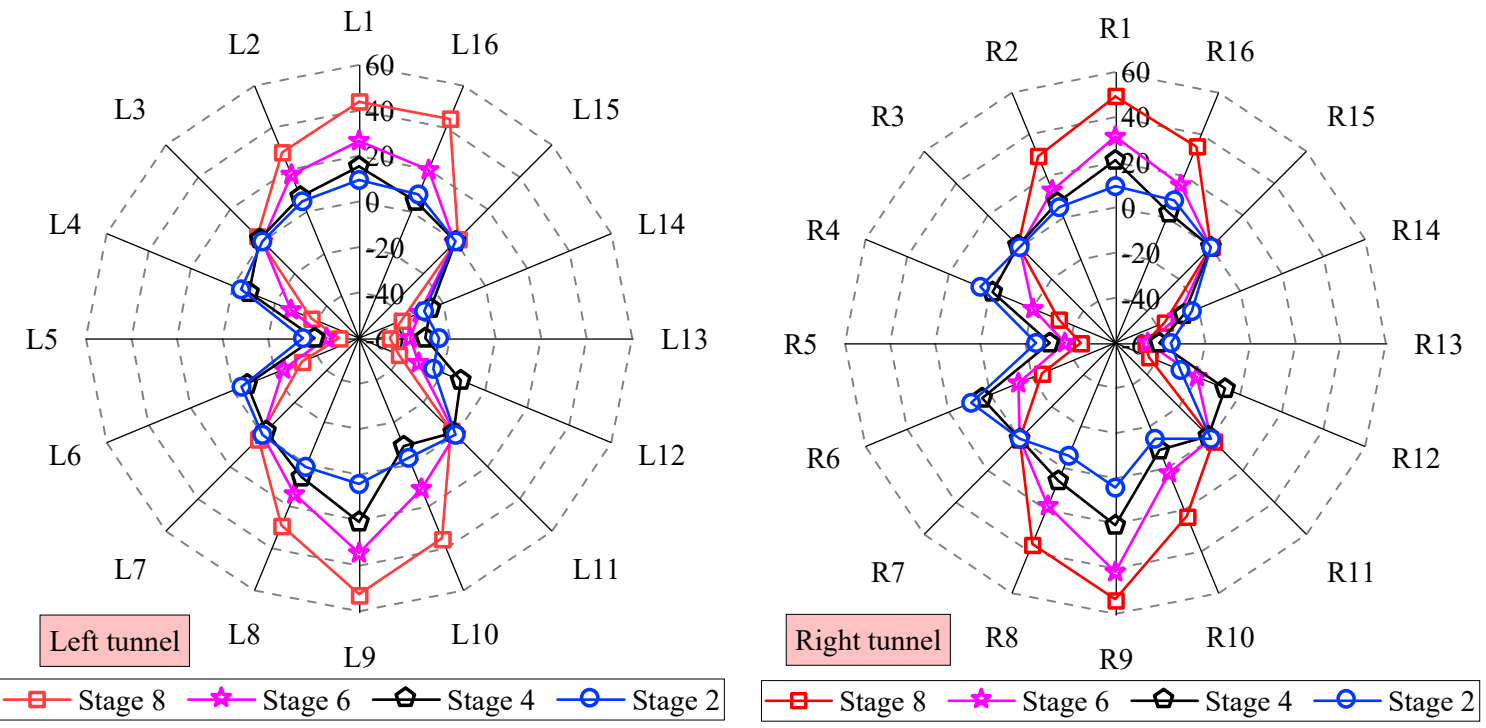

Figure 11. Variation of bending moment with excavation stage (unit: $\mathrm{kN} \cdot \mathrm{m}$ ). 


\subsection{Tunnel Axial Force}

Figure 12 illustrates the axial forces at tunnel transverse sections before and after excavation. It can be seen that the excavation-induced unloading effect above the tunnels results in considerable variations of the tunnel axial force distribution. Before the excavation, the axial forces at the side walls of the tunnels are larger than these at the crowns and inverts. The axial forces at the upper part of the tunnels are slightly smaller than these at the lower part. The maximum axial force values for the left and right tunnels are $654.88 \mathrm{kN}$ and $663.71 \mathrm{kN}$, which are recorded at measurement points L9 and R8, respectively, both of them were close to the inverts of the tunnels. After excavation, the axial forces at all tunnel parts are decreased to varying degrees. The variation in axial forces at side walls of the tunnels is significantly greater than that at the crowns and inverts. The locations of the maximum axial force are basically unchanged. As can been seen from Figure 10, the axial forces at or near the side walls of the tunnels are the most sensitive to the excavation unloading, with reductions of $194.72 \mathrm{kN}$ and $181.72 \mathrm{kN}$ at the $\mathrm{L} 5$ and $\mathrm{R} 12$ regions. The axial forces undergo excavation-induced decreases of about $31.96 \%$ and $29.65 \%$, respectively, compared with before excavation. The variations of axial forces at crowns and inverts of tunnels are not significant. In this case, axial forces at the left tunnel crown and the invert are decreased by $7.05 \%$ and $4.84 \%$, respectively, while these at right tunnel the crown and invert axial forces are decreased by $9.05 \%$ and $6.11 \%$, respectively.
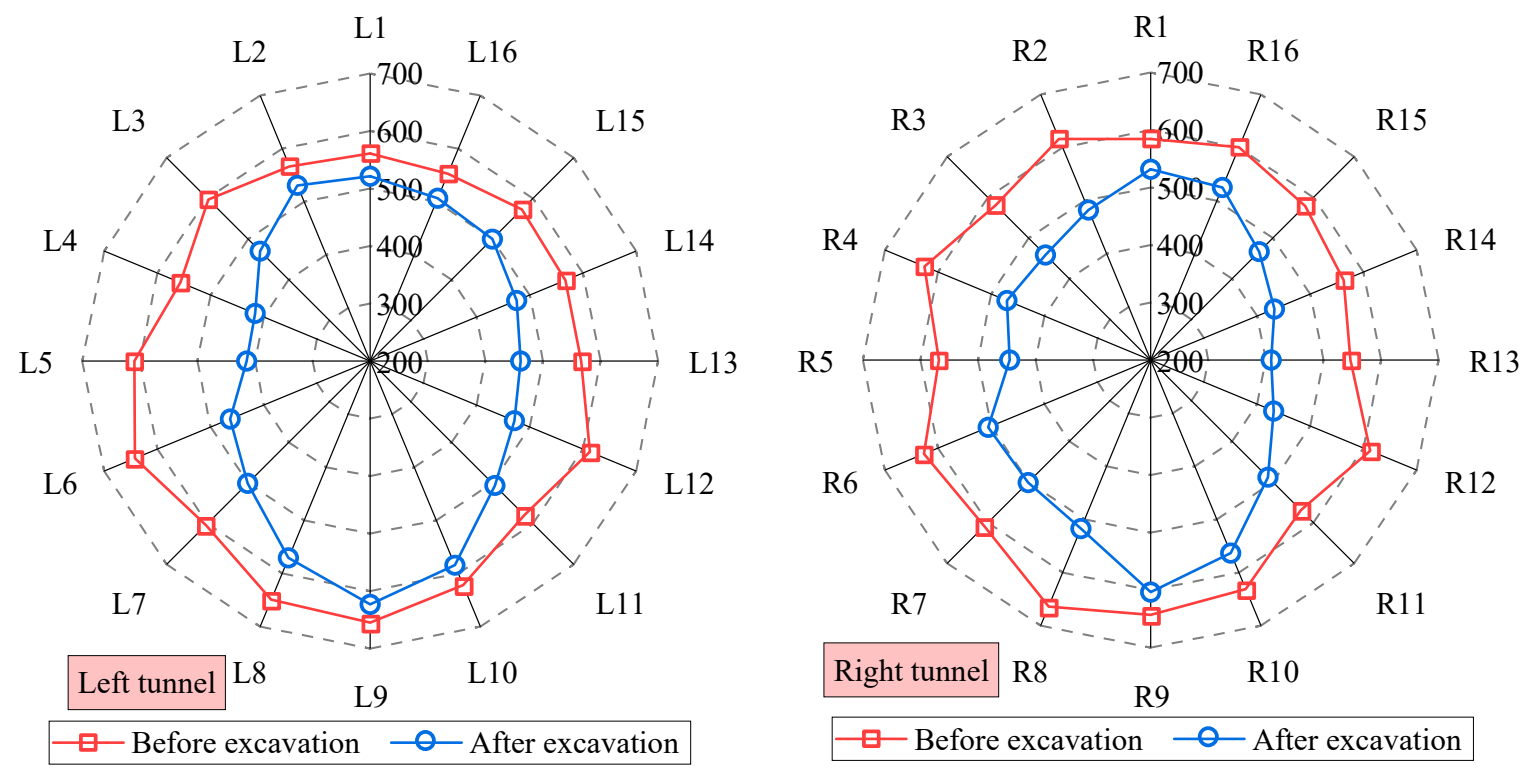

Figure 12. Variation of tunnel axial force before and after excavation (unit: kN).

\section{Numerical Parametric Study on Tunnel Displacement}

\subsection{Numerical Program}

In the numerical analysis, various factors including the clearance between the bottom of the foundation pit and the crown of the tunnel $(H)$, the excavation length of the foundation pit $\left(L_{p}\right)$, and the unloading ratio, are considered to explore their influence on tunnel deformation responses, which are summarized in Table 3. It is also noted that all these geometric parameter symbols are consistent with those in Figure 1 . The $H$ values are set from 3 to $30 \mathrm{~m}$, and the corresponding $H / H_{p}$ ratios are varied from 0.375 to 3.75 . Different excavation length variations of the foundation pit were examined to study its effect on tunnel displacement responses. The $L_{p}$ values were in the range of 8-56 m, with $L_{p} / H_{p}$ ratios of 1-7. For the analysis of influence of the unloading ratio $\left(H_{e} / D_{t}\right)$ on the tunnel responses, the numerical runs consider the $C_{t} / D_{t}$ ratios varying from 1.83 to 6.33 , and the corresponding $H_{e} / C_{t}$ ratios are varied from 0.053 to 0.72 . In all cases, the final excavation 
depth $\left(H_{p}\right)$ and depth $\left(W_{p}\right)$ are consistent with the prototype scale, with given values of $8 \mathrm{~m}$ and $20 \mathrm{~m}$.

Table 3. Parameters considered on tunnel displacement responses by overlying foundation excavation.

\begin{tabular}{|c|c|c|c|c|c|c|c|c|c|}
\hline \multicolumn{3}{|c|}{$\begin{array}{c}\text { Parametric Setup for Influence } \\
\text { of } H / H_{e} \text { Ratio }\end{array}$} & \multicolumn{3}{|c|}{$\begin{array}{l}\text { Parametric Setup for Influence of } \\
\qquad B / H_{e} \text { Ratio }\end{array}$} & \multicolumn{4}{|c|}{ Parametric Setup for Influence of Unloading Ratio } \\
\hline$H / \mathrm{m}$ & $H_{p} / \mathrm{m}$ & $H / H_{p}$ Ratio & $L_{p} / \mathrm{m}$ & $W_{p} / \mathrm{m}$ & $L_{p} / H_{p}$ Ratio & $C_{t} / \mathrm{m}$ & $D_{t} / \mathrm{m}$ & $C_{t} / D_{t}$ Ratio & Unloading Ratio \\
\hline 3 & & 0.375 & 8 & & 1 & 11 & & 1.83 & $0.18-0.72$ \\
\hline 6 & & 0.75 & 16 & & 2 & 14 & & 2.33 & $0.14-0.56$ \\
\hline 9 & & 1.125 & 24 & & 3 & 17 & & 2.83 & $0.12-0.47$ \\
\hline 12 & 8 & 1.5 & 32 & 20 & 4 & 20 & 6 & 3.33 & $0.1-0.4$ \\
\hline 18 & & 2.25 & 40 & & 5 & 26 & & 4.33 & $0.077-0.308$ \\
\hline 24 & & 3 & 48 & & 6 & 32 & & 5.33 & $0.0625-025$ \\
\hline 30 & & 3.75 & 56 & & 7 & 38 & & 6.33 & $0.053-0.211$ \\
\hline
\end{tabular}

\subsection{Modeling and Validation}

Numerical modelling is performed with the finite element commercial package FLAC $^{3 \mathrm{D}}$ to identify the tunnel displacement responses to the overlying foundation pit excavation. A three-dimensional model with dimensions of $140 \mathrm{~m} \times 140 \mathrm{~m} \times 60 \mathrm{~m}$ is finally developed to minimize the boundary effects. Soil, diaphragm wall and segment lining are modelled by solid elements, while steel supports are modelled using beam elements. Soil parameters are presented in Table 1, and the supporting structures' parameters utilized in the modelling are illustrated in Table 4 . The three-dimensional finite element-model mesh adopted for numerical analysis is displayed in Figure 13.

Table 4. Material parameters of supporting structures.

\begin{tabular}{cccc}
\hline Material & $\gamma\left(\mathbf{k N} / \mathbf{m}^{\mathbf{3}}\right)$ & $\boldsymbol{E}(\mathbf{G P a})$ & $\boldsymbol{\mu}$ \\
\hline Diaphragm wall & 22.54 & 28.0 & 0.2 \\
Steel support & 78.5 & 206.0 & 0.2 \\
Segment liner & 25.0 & 34.5 & 0.2 \\
\hline
\end{tabular}
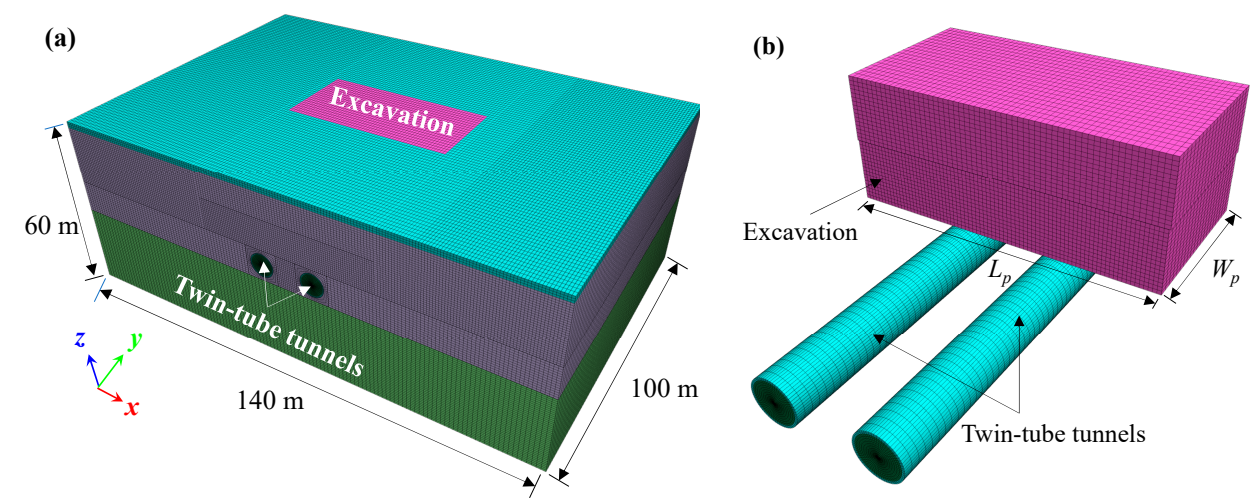

Figure 13. 3D finite element mesh, (a) the whole mesh, (b) location relationship between foundation and twin-tube tunnels.

A comparison of the displacement and earth pressure of the left tunnel with the experimental tests for numerical validation is plotted in Figures 14 and 15. It can be seen that the numerical results are larger than the model test results, but the two results are highly comparable in terms of variation trends, which can effectively provide assurance and support for in-depth parametric analysis on tunnel responses. Additionally, it confirms that the tunnel heave at the crown is larger than that at the invert. Meanwhile, the horizontal 
displacement at the near-pit side (L13) is slightly smaller than that at the away-from-pit side (L5).
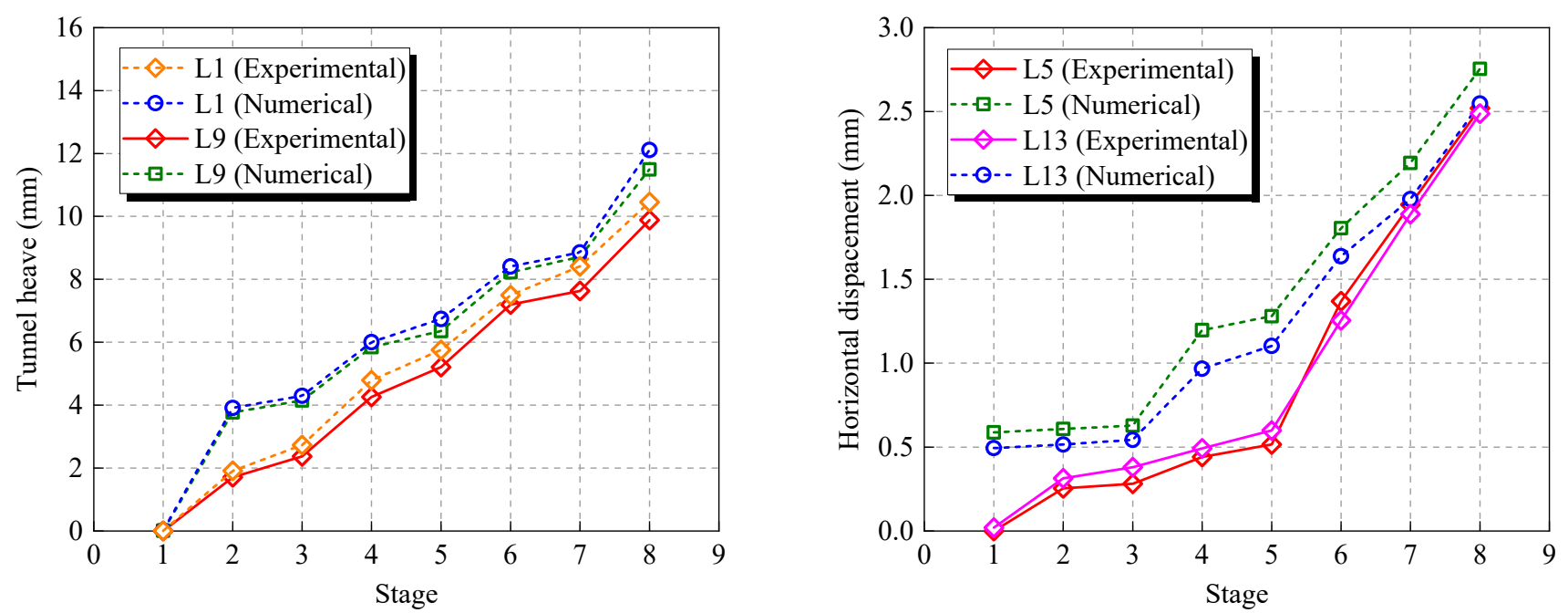

Figure 14. Comparison of tunnel displacements between numerical simulation and experimental test.
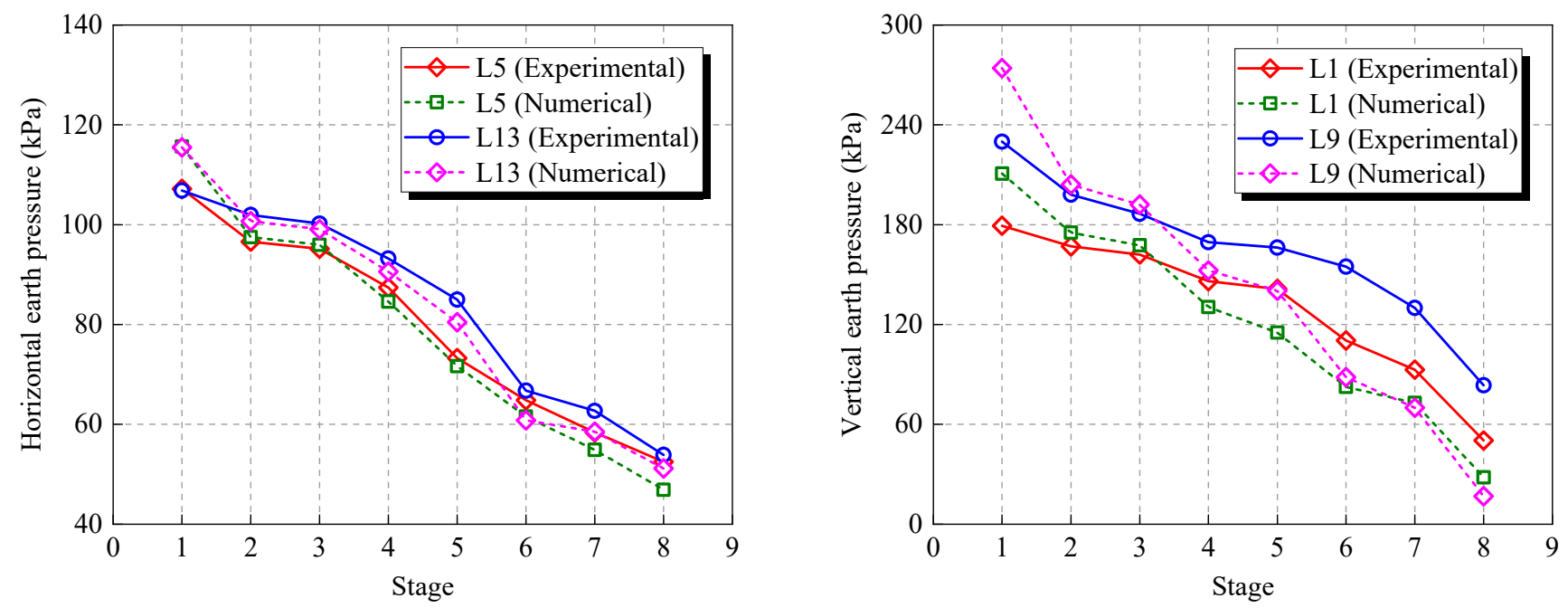

Figure 15. Comparison of earth pressure between numerical simulation and experimental test.

\subsection{Effect of Cover-to-Depth Ratio}

As the clearance $(H)$ between the bottom of the foundation pit and the crown of the tunnel increases, the impact on the tunnels caused by the excavation and unloading would gradually decrease. The tunnel displacement responses with variations of the $H / H_{p}$ ratios are analyzed in depth. The $H$ values are set as $3 \mathrm{~m}, 6 \mathrm{~m}, 9 \mathrm{~m}, 12 \mathrm{~m}, 18 \mathrm{~m}, 24 \mathrm{~m}, 30 \mathrm{~m}$, $36 \mathrm{~m}$ in the numerical runs, and the monitoring point arrangement is the same as Figure 5 descripted previously. Figure 16 shows the variations of tunnel heaves and horizontal displacements with different $H / H_{p}$ ratios after the excavation completed. The results confirm that both the tunnel heaves and horizontal displacements gradually decrease with the increase in the $H / H_{p}$ ratios, and the tunnel heave is much larger than the horizontal displacement. The heave and horizontal displacement differences of the tunnel gradually decrease with the increases in the $H / H_{p}$ ratios. The tunnel heave is less than $2 \mathrm{~mm}$ when the $H / H_{p}$ ratio is greater than 3.5 , at this time the influence of excavation unloading on the tunnel deformation responses is marginal. 

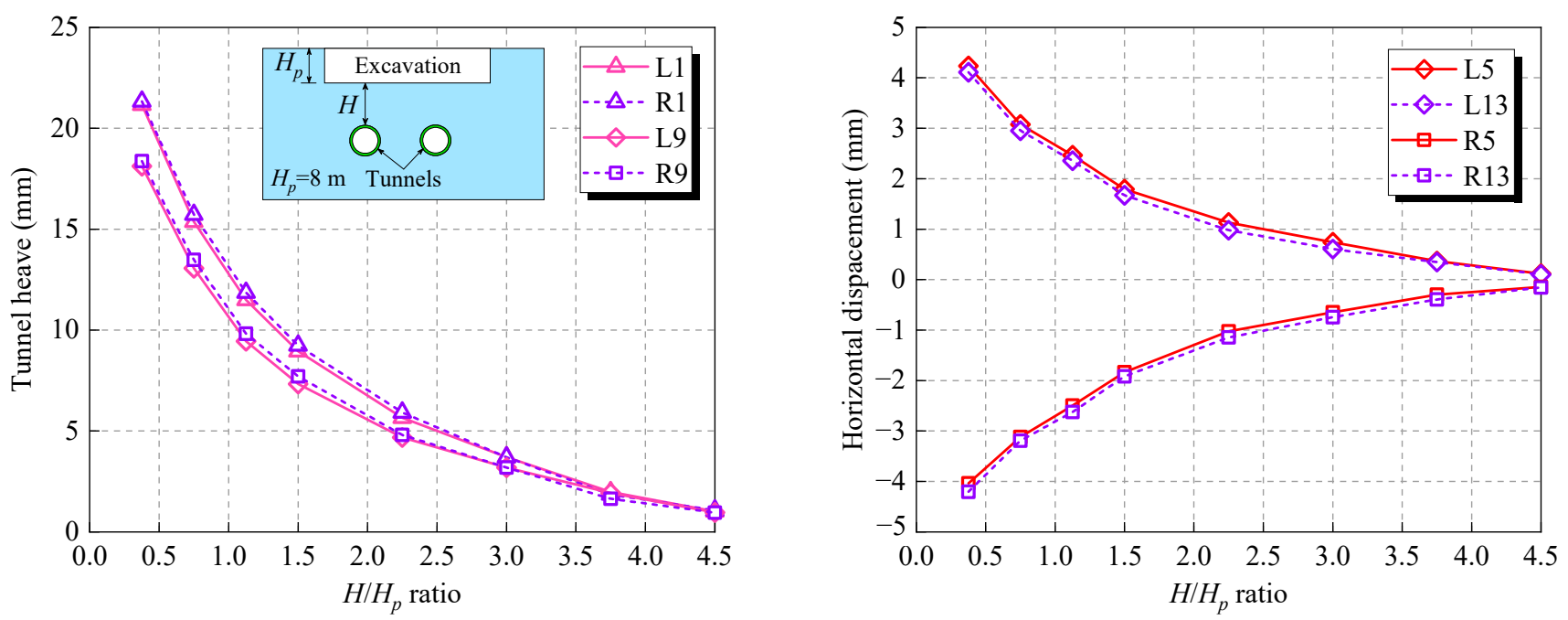

Figure 16. Influence of $H / H_{p}$ ratio on tunnel displacement.

\subsection{Effect of Length-to-Depth Ratio}

Figure 17 presents the relationship between the tunnel heave, horizontal displacement and varying $L_{p} / H_{p}$ ratios, with a final $H_{p}$ value of $8 \mathrm{~m}$. The $L_{p}$ values along the transversal tunnel direction are assumed to be from $8 \mathrm{~m}$ to $56 \mathrm{~m}$, so as to explore geometrical effects of an excavation on tunnel responses. At a given $H_{p}$ value, the tunnel heave and horizontal displacement are found to increase with increase in the $L_{p} / H_{p}$ ratio, but at a reduced rate. The maximum heave and horizontal displacement are obtained when the $L_{p} / H_{p}$ ratio is 7 . In this case, the tunnel heave and horizontal displacement at stage 1 increases from 5.16 and $0.45 \mathrm{~mm}$, to 14.5 and $3.33 \mathrm{~mm}$ at stage $8(181 \%$ and $640 \%$ change, respectively; note only the larger values of these two indicators in twin-tube tunnels are presented), which proves a more significant effect on horizontal displacement increasement. Moreover, the maximum incremental tunnel heave and horizontal displacement are less than $4.1 \%$ and $2.4 \%$ when the $L_{p} / H_{p}$ ratio varies from 6 to 7 . It is demonstrated that the increased $L_{p}$ values contributing to developments of tunnel heave and horizontal displacement are marginal when the $L_{p} / H_{p}$ ratio larger than 6 . Due to a more positive response of tunnel horizontal displacement, countermeasures may be necessary to minimize the adverse impact of excavation on existing tunnels.
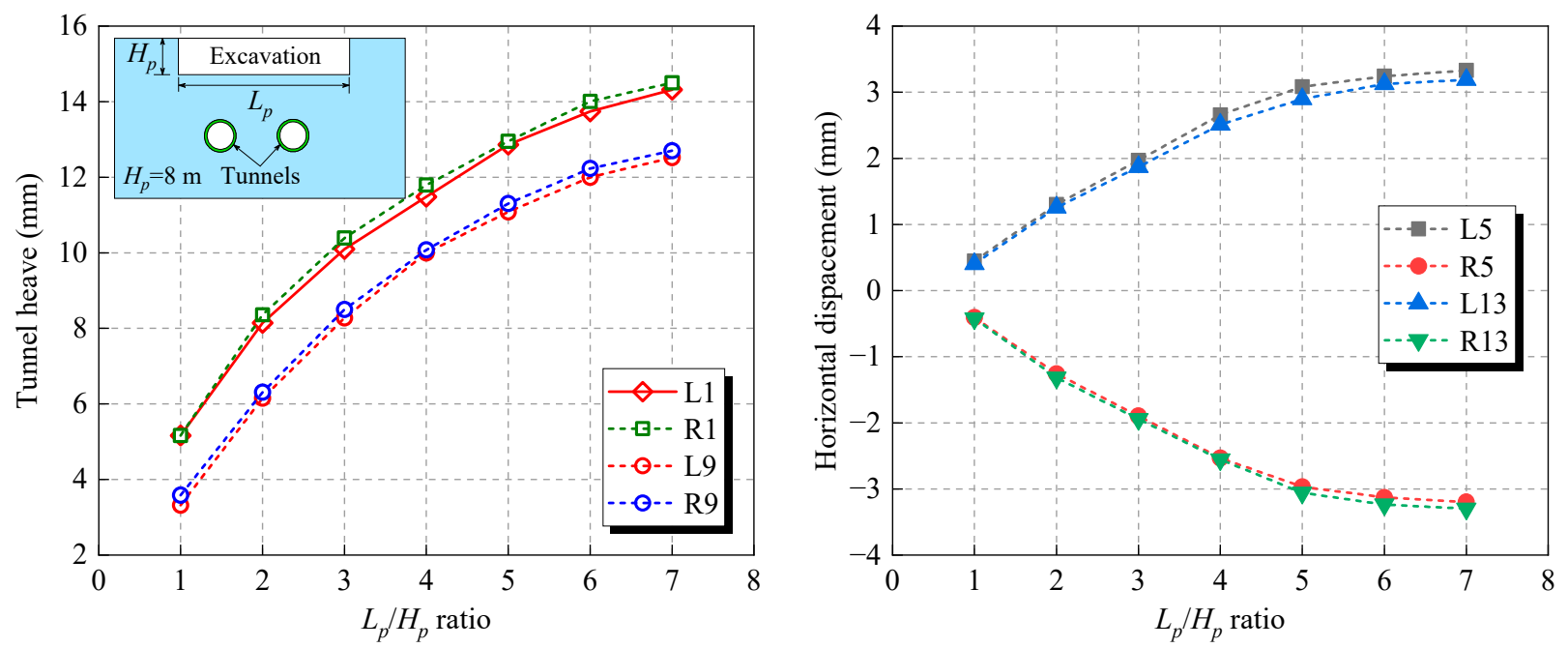

Figure 17. Influence of $L_{p} / H_{p}$ ratio on tunnel displacement. 


\subsection{Effect of Unloading Ratio}

The unloading ratio was defined as excavation depth (described as $H_{e}, H_{e}=H_{p}=8 \mathrm{~m}$ when the excavation completed) over initial tunnel cover depth $\left(C_{t}\right)$. For this purpose, different unloading ratios $\left(H_{e} / C_{t}\right)$ are considered to investigate the tunnel responses to an excavation. All the computed results are normalized by a final $H_{p}$ value of $8 \mathrm{~m}$; thereafter each $H_{e} / C_{t}$ ratio is determined by four excavations ( $2 \mathrm{~m}$ in each excavation advance). Figure 18 shows the relationship between the tunnel heave, horizontal displacement and the $H_{e} / C_{t}$ ratios. At each $C_{t} / D_{t}$ ratio, it can be seen that both the tunnel heave and horizontal displacement increase with the increasing $H_{e} / C_{t}$ ratio, at an increased rate. This confirms that excavation advancement leads to a larger increment in tunnel heave and horizontal displacement when the stress relief is controlled at the same magnitude. This is mainly due to the stress relief around the tunnel increasing as the $H_{e} / C_{t}$ ratio is increased. Moreover, the final tunnel heave and horizontal displacement in the two typical cases (e.g., with $C_{t} / D_{t}$ ratios of 5.33 and 1.83) vary from 3.7 and $0.74 \mathrm{~mm}$, to 21.16 and $4.23 \mathrm{~mm}$, when the excavation is completed $(471.89 \%$ and $131.15 \%$ change for tunnel heave and horizontal displacement, respectively.). Obviously, the tunnel heave is more sensitive to the change of the $C_{t} / D_{t}$ ratio. Additionally, it is demonstrated that at a given $H_{e} / C_{t}$ ratio, the maximum heave and horizontal displacements of tunnel decrease as the $C_{t} / D_{t}$ ratios increase. Therefore, it is strongly recommended that more attention should be paid to excavation activities above the existing tunnels with a shallower initial cover depth.
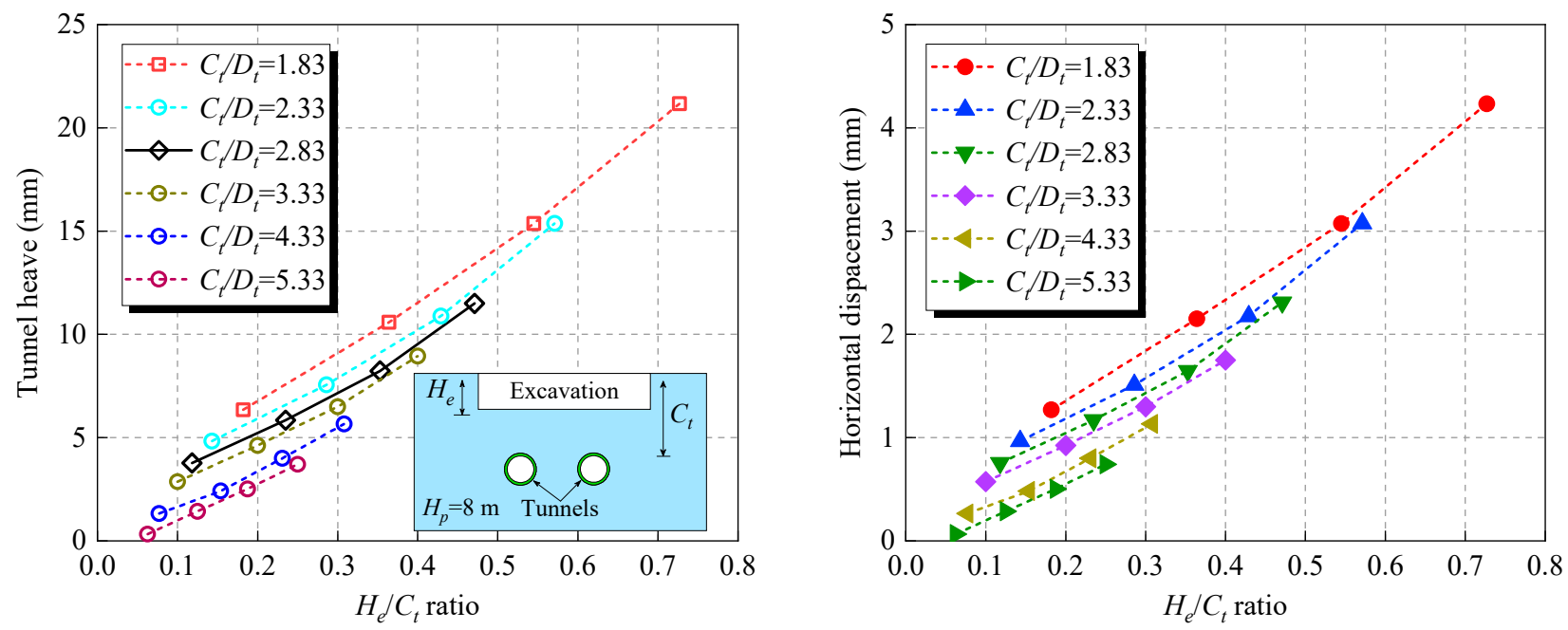

Figure 18. Influence of unloading ratio on tunnel displacement.

\subsection{Effect of $K_{0}$ (Horizontal/Vertical Stress Ratio)}

It is well recognized that the coefficient of lateral pressure (the horizontal/vertical stress ratio, $K_{0}$ ) may lead to different mechanical responses of underground engineering structures [38,39]. In this section, the effect of varying $K_{0}$ values on tunnel displacement responses is examined, thereafter the $K_{0}$ values of $0.5,1$, and 2 are considered, with the tunnel and excavation geometries in prototype scale being modeled. The calculated tunnel heave and horizontal displacement at different stages with varying $K_{0}$ values are shown in Figure 19. This indicates that increasing the $K_{0}$ significantly increases the effect of the excavation on the tunnel displacements. At each $K_{0}$, excavation-induced tunnel heave and horizontal displacement are both increased as the excavation proceeds, and the maximum values are obtained at the last stage, as expected. At each stage, the tunnel heave and horizontal displacement both experience increases at an increased rate as the $K_{0}$ values increase from 0.5 to 2.0. The terminal values also increase with increasing $K_{0}$ values, so the maximum tunnel heave and horizontal displacement are simultaneously obtained when the $K_{0}$ is 2 . Increasing $K_{0}$ results in a more significant increase in tunnel heave than horizontal displacement. 

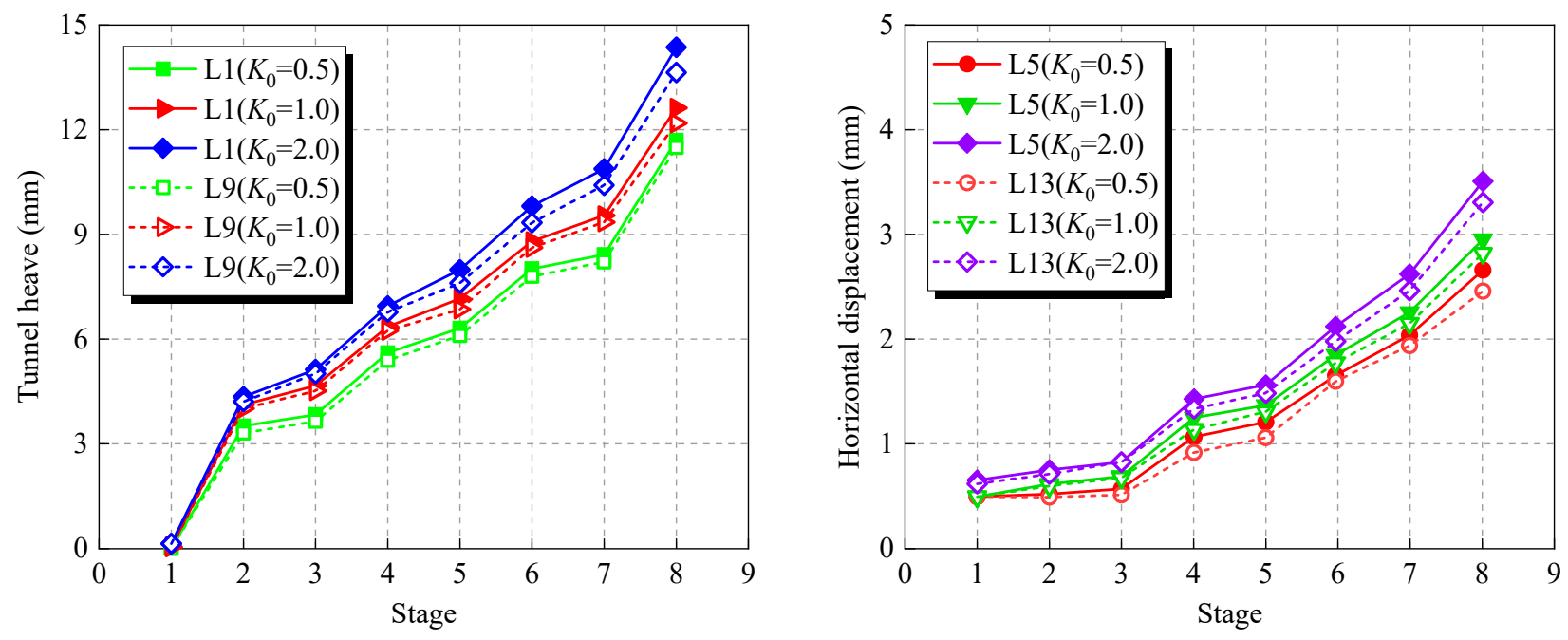

Figure 19. Influence of $K_{0}$ on tunnel displacement.

\section{Conclusions}

Experimental tests and extensive numerical analyses considering different factors have been performed to explore the influence of the overlying foundation excavation on the existing twin-tube shield tunnels. The following conclusions can be drawn:

(1) As a result of the excavation, the tunnels undergo heaves and horizontal displacement, and the tunnel linings are placed in compression at the side walls and in tension at crown and invert. The changes of the earth pressure at tunnel crown and invert are significantly greater than that at side walls.

(2) Excavation also causes significant changes in the axial forces and the bending moments at tunnel side walls, especially the tunnel-liner side near the foundation pit. So, it is recommended for designers to consider these effects and a more reserved capacity of tunnel liner while designing the tunnels in possible excavation areas, so as to ensure that these tunnels operate safely.

(3) The parametric analysis confirms that the factors, including the cover depth of the tunnel, the length and unloading ratio of excavation as well as the lateral pressure coefficient, impose significant effects on tunnel displacement responses. Therefore, it is also suggested that these influential factors need to be fully considered during the design and construction of, or countermeasures employed to, an excavation adjacent to existing tunnels.

(4) In this study, a reduced-scale experimental test was carried out to analyze excavationassociated issues, which is meaningful work in developing the research for underlying tunnel stability. It should also be noted that the reported findings do not consider the axis distortion effects resulting from the tunnel-soil interactions. For this purpose, further research on this subject will be conducted in order to more effectively evaluate the deformational and structural response of tunnels due to excavation activities.

Author Contributions: Conceptualization, X.C. (Xiaodong Cheng) and T.H.; methodology, T.H.; software, X.C. (Xiaodong Cheng); validation, T.H. and X.C. (Xiaochun Cheng); formal analysis, X.C. (Xiaochun Cheng); investigation, X.C. (Xiaodong Cheng); resources, T.H.; data curation, X.C. (Xiaodong Cheng); writing-original draft preparation, X.C. (Xiaodong Cheng); writing-review and editing, Z.L.; visualization, X.C. (Xiaodong Cheng); supervision, T.H.; funding acquisition, Z.L. All authors have read and agreed to the published version of the manuscript.

Funding: This research was funded by National Natural Science Foundation of China, grant number 41807266; Natural Science Foundation of Anhui Province, grant number 1808085QD112.

Institutional Review Board Statement: Not applicable. 
Informed Consent Statement: Not applicable.

Data Availability Statement: The data use for the present study have been included in the paper.

Conflicts of Interest: The authors declare no conflict of interest.

\section{References}

1. Lin, D.; Nelson, J.D.; Beecroft, M.; Cui, J.Q. An overview of recent developments in China's metro systems. Tunn. Undergr. Space Technol. 2021, 111, 103783. [CrossRef]

2. Xu, J.; Xiao, C.; Wu, H.N.; Kang, X. Reuse of excavated clayey silt in cement-fly ash-bentonite hybrid back-fill grouting during shield tunneling. Sustainability 2020, 12, 1017. [CrossRef]

3. Zhu, Y.M.; Chen, L.; Zhang, H.; Tu, P.; Chen, S.G. Quantitative analysis of soil displacement induced by ground loss and shield machine mechanical effect in metro tunnel construction. Appl. Sci. 2019, 9, 3028. [CrossRef]

4. Zhang, J.F.; Zhao, M. Monitoring system for circular deformation in metro shield tunnels in soft soils. Adv. Civ. Eng. 2020, 2020, 8886402. [CrossRef]

5. Dias, D.; Kastner, R. Movements caused by the excavation of tunnels using face pressurized shields-Analysis of monitoring and numerical modeling results. Eng. Geol. 2013, 152, 17-25. [CrossRef]

6. Liang, R.Z.; Xia, T.D.; Hong, Y.; Yu, F. Effects of above-crossing tunnelling on the existing shield tunnels. Tunn. Undergr. Space Technol. 2016, 58, 159-176. [CrossRef]

7. Cooper, M.L.; Chapman, D.N.; Rogers, C.D.F.; Chan, A.H.C. Movements in the piccadilly line tunnels due to the Heathrow Express construction. Geotechnique 2002, 52, 243-257. [CrossRef]

8. Tan, Y.; Li, X.; Kang, Z.J.; Liu, J.X.; Zhu, Y.B. Zoned excavation of an oversized pit close to an existing metro line in stiff clay: Case study. J. Perform. Constr. Facil. 2015, 29, 04014158. [CrossRef]

9. $\mathrm{Ng}$, C.W.; Shi, J.W.; Hong, Y. Three-dimensional centrifuge modelling of basement excavation effects on an existing tunnel in dry sand. Can. Geotech. J. 2013, 50, 874-888. [CrossRef]

10. Liu, B.; Yu, Z.W.; Hang, Y.H.; Wang, Z.L.; Yang, S.; Liu, H. A simplified combined analytical method for evaluating the effect of deep surface excavations on the shield metro tunnels. Geomech. Eng. 2020, 23, 405-418. [CrossRef]

11. Huang, X.; Schweiger, H.F.; Huang, H.W. Influence of deep excavations on nearby existing tunnels. Int. J. Geomech. 2013, 13, 170-180. [CrossRef]

12. Huang, X.; Huang, H.W.; Zhang, D.M. Centrifuge modelling of deep excavation over existing tunnels. Proc. Inst. Civ. Eng. Geotech. Eng. 2014, 167, 3-18. [CrossRef]

13. Zhang, J.F.; Chen, J.J.; Wang, J.H.; Zhu, Y.F. Prediction of tunnel displacement induced by adjacent excavation in soft soil. Tunn. Undergr. Space Technol. 2013, 36, 24-33. [CrossRef]

14. Chen, R.P.; Meng, F.Y.; Li, Z.C.; Ye, Y.H.; Ye, J.N. Investigation of response of metro tunnels due to adjacent large excavation and protective measures in soft soils. Tunn. Undergr. Space Technol. 2016, 58, 224-235. [CrossRef]

15. Zhang, X.H.; Wei, G.; Jiang, C.W. The study for longitudinal deformation of adjacent shield tunnel due to foundation pit excavation with consideration of the retaining structure deformation. Symmetry 2020, 12, 2103. [CrossRef]

16. Li, M.G.; Xiao, X.; Wang, J.H.; Chen, J.J. Numerical study on responses of an existing metro line to staged deep excavations. Tunn. Undergr. Space Technol. 2019, 85, 268-281. [CrossRef]

17. Avgerinos, V.; Potts, D.M.; Standing, J.R. Numerical investigation of the effects of tunnelling on existing tunnels. Géotechnique 2017, 67, 1-15. [CrossRef]

18. Meng, F.Y.; Chen, R.P.; Liu, S.L.; Wu, H.N. Centrifuge modeling of ground and tunnel responses to nearby excavation in soft clay. J. Geotech. Geoenvironmental Eng. 2021, 147, 04020178. [CrossRef]

19. Zhang, X.M.; Ou, X.F.; Yang, J.S.; Fu, J.Y. Deformation response of an existing tunnel to upper excavation of foundation pit and associated dewatering. Int. J. Geomech. 2017, 17, 04016112. [CrossRef]

20. Sun, H.S.; Chen, Y.D.; Zhang, J.H.; Kuang, T.S. Analytical investigation of tunnel deformation caused by circular foundation pit excavation. Comput. Geotech. 2019, 106, 193-198. [CrossRef]

21. Meng, F.Y.; Chen, R.P.; Xu, Y.; Wu, K.; Wu, H.N.; Liu, Y. Contributions to responses of existing tunnel subjected to nearby excavation: A review. Tunn. Undergr. Space Technol. 2022, 119, 104195. [CrossRef]

22. Li, M.G.; Chen, J.J.; Wang, J.H.; Zhu, Y.F. Comparative study of construction methods for deep excavations above shield tunnels. Tunn. Undergr. Space Technol. 2018, 71, 329-339. [CrossRef]

23. Ng, C.W.W.; Shi, J.W.; Masin, D.; Sun, H.S.; Lei, G.H. Influence of sand density and retaining wall stiffness on three-dimensional responses of tunnel to basement excavation. Can. Geotech. J. 2015, 52, 1811-1829. [CrossRef]

24. Liu, T.J.; Chen, S.W.; Liu, H.Y. Deformation characterisation and distress diagnosis of a metro shield tunnel by adjacent constructions. Adv. Civ. Eng. 2020, 2020, 4216349. [CrossRef]

25. Sharma, J.S.; Hefny, A.M.; Zhao, J.; Chan, C.W. Effect of large excavation on deformation of adjacent MRT tunnels. Tunn. Undergr. Space Technol. 2001, 16, 93-98. [CrossRef]

26. Zhang, Z.G.; Huang, M.S.; Wang, W.D. Evaluation of deformation response for adjacent tunnels due to soil unloading in excavation engineering. Tunn. Undergr. Space Technol. 2013, 38, 244-253. [CrossRef] 
27. Han, J.Y.; Zhao, W.; Jia, P.J.; Guan, Y.P.; Chen, Y.; Jiang, B.F. Risk analysis of the opening of shield-tunnel circumferential joints induced by adjacent deep excavation. J. Perform. Constr. Facil. 2018, 32, 04017123. [CrossRef]

28. Zheng, G.; Yang, X.Y.; Zhou, H.Z.; Du, Y.M.; Sun, J.Y.; Yu, X.X. A simplified prediction method for evaluating tunnel displacement induced by laterally adjacent excavations. Comput. Geotech. 2018, 95, 119-128. [CrossRef]

29. Doležalová, M. Tunnel complex unloaded by a deep excavation. Comput. Geotech. 2001, 28, 469-493. [CrossRef]

30. Zheng, G.; Du, Y.M.; Cheng, X.S.; Diao, Y.; Deng, X.; Wang, F.J. Characteristics and prediction methods for tunnel deformations induced by excavations. Geomech. Eng. 2017, 12, 361-397. [CrossRef]

31. Liang, R.Z.; Xia, T.D.; Huang, M.S.; Lin, C.G. Simplified analytical method for evaluating the effects of adjacent excavation on shield tunnel considering the shearing effect. Comput. Geotech. 2017, 81, 167-187. [CrossRef]

32. Hu, X.R.; Zhou, Z.G.; Chen, H.; Ren, Y.Q. Seismic fragility analysis of tunnels with different buried depths in a soft soil. Sustainability 2020, 12, 892. [CrossRef]

33. Yang, A.L. Research on Influence of Existing Tunnel Deformation Caused by Foundation Pit Excavation above Subway. Master's Thesis, Henan University of Technology, Zhengzhou, China, 2020.

34. Fumagalli, E. Statical and Geomechanical Models; Springer: Vienna, Austria, 1973.

35. Liu, J.; Feng, X.T.; Ding, X.L.; Zhang, J.; Yue, D.M. Stability assessment of the Three-Gorges Dam foundation, China, using physical and numerical modeling-Part I: Physical model tests. Int. J. Rock Mech. Min. Sci. 2003, 40, 609-631. [CrossRef]

36. Fumagalli, E. Geomechanical models of dam foundation. In Proceedings of the International Colloquium on Physical GeoMechanical Models, Bergamo, Italy, 29-30 March 1979.

37. Zhang, Q.Y.; Li, S.C.; Li, Y.; Chen, X.G. New Methods, Techniques and Engineering Applications of Underground Engineering Modeling Tests; Science Press: Beijing, China, 2012; pp. 6-14.

38. Reza, B.A.; Vojtech, G. 3D numerical parametric study of the influence of open-pit mining sequence on existing tunnels. Tunn. Undergr. Space Technol. 2017, 27, 459-466. [CrossRef]

39. Hejazi, Y.; Dias, D.; Kastner, R. Impact of constitutive models on the numerical analysis of underground constructions. Acta Geotech. 2008, 3, 251-258. [CrossRef] 